9 Fallon RJ. Laboratory diagnosis of legionnaires' disease. London: British Medical Association/Association of Clinical Pathologists, 1981. (Broadsheet 99.)

10 Fallon RJ, Abraham WH. Legionella infections in Scotland. fournal of Hygiene (Cambridge) 1982;89:439-48.

11 Wilkinson HW, Brake BJ. Formalin-killed versus heat-killed Legionella pneumophila serogroup 1 antigen in the indirect immunofluorescence assay for legionellosis. I Clin Microbiol 1982;16:979-81.

12 Pastoris MC, Ciarrochi S, Di-Capua A, Temperanza AM. Comparison of phenol- and heat-killed antigens in indirect immunofluorescence test for phen- and hat for 780-3.

13 'Timbury MC, Donaldson JR, McCartney AC, et al. Outbreak of legionnaires' disease in Glasgow Royal Infirmary: microbiological aspects. Fournal of Hygiene (Cambridge) 1986;97:393-403.

14 Bhopal RS, Barr G. Maintenance of cooling towers following two outbreaks of legionnaires' disease in a city. Epidemiol Infect 1990;104:29-38.

15 General Register Office for Scotland. Postcode directory user guide. 1. General Register Office (Scotland), Edinburgh: 1986.

$16 \mathrm{Nimmo}$ AW. Review of computer mapping of health data. Health Bull (Edinb) 1989;47:40-53.

17 Breslow NE, Day NE. Statistical methods in cancer research. Vol 2. The design and analysis of cohort studies. Lyons: International Agency for Research on Cancer, 1987. (IARC Scientific Publications, No 82. )

18 Anonymous. How common is legionnaires' disease? Lancet 1983;i:103-4.

19 Bhopal RS, Fallon RJ. Variation in time and space of non-outbreak legionnaires' disease in Scotland. Epidemiol Infect (in press).

20 Devenay WT. Water supply from Loch Katrine to Glasgow and environs. Glasgow: Strathclyde Regional Council, (undated).
21 Bollin GE, Plouffe JE, Para MF, Hackman B. Aerosols containing Legionella pneumophila generated by shower heads and hot-water faucets. Appl Environ Microbiol 1985;50:1128-31.

22 Committee of Inquiry into Outbreak of Legionnaires' Disease in Stafford in April 1985. Second report. London: HMSO, 1987.

23 Klaucke DN, Vogt RL, La Rue D, et al. Legionnaires' disease: the epidemiology of 2 outbreaks in Burlington, Vermont 1980. Am f Epidemio 1984;119:382-91

24 Dondero TJ, Rendtorff RC, Mallison GF, et al. An outbreak of legionnaires' disease associated with a contaminated air-conditioning cooling tower. $N$ Engl f Med 1980;302:365-70.

25 Addiss DG, Davis JP, Wand PJ, McKinney RM, Gradus HS, Martins RR. Two cases of community-acquired legionnaires' disease: evidence fo association with a cooling tower. $\mathcal{F}$ Infect Dis 1989;159:572-5.

26 Westminster Action Committee. Broadcasting House legionnaires' disease. London: Westminster City Council, 1988.

27 Addiss DG, Davis JP, La Venture M, Wand PJ, Hutchinson MA, McKinney RM. Community-acquired legionnaires' disease associated with a coolin tower: evidence for longer-distance transport of Legionella pneumophila. Am F Epidemiol 1989;130:557-68.

28 Bovallius A, Roffey R, Henningston E. Long-range transmission of bacteria. Ann N Y Acad Sci 1980;353:186-97.

29 Muder RR, Yu VL, Woo AH. Mode of transmission of Legionella pneumophila. A critical review. Arch Intern Med 1986;146:1607-12.

30 Stout JE, Yu VL, Muroca P. Legionnaires' disease acquired within the homes of two patients. Link to the home water supply. $\mathscr{J} A M A$ 1987;257:1215-7.

(Accepted 13 November 1990)

\title{
Underprivileged areas and health care planning: implications of use of Jarman indicators of urban deprivation
}

\author{
Robin J Talbot
}

\section{Abstract}

Objective-To analyse critically the use of the Jarman underprivileged area index in health care planning and distribution of resources.

Design - The original derivation of the score was examined and evidence to support criticisms of the use of underprivileged area scores examined.

Main outcome measures-Discrepancies between areas classified as deprived according to the index and areas known to require government funding; the extent of the bias towards family practitioner areas in London; and how the results of using the Jarman index compared with those when another deprivation index based on different indicators was used.

Results-The use of electoral wards as geographical areas for which deprivation payments are made is unsatisfactory as the wards vary considerably in size. Of the 20 district health authorities with the highest underprivileged area scores in England, 12 were in London, and four of the six family practitioner committee areas with the highest scores were in London. No health authority or family practitioner committee area in the Northern region had one of the top 20 or 10 scores respectively. When an alternative deprivation index was used to determine the allocation of resources to doctors there was considerable variation compared with the Jarman index.

Conclusion-The Jarman index underprivileged area score is an inappropriate measure to use for health care planning and distribution of resources. There is a need for a revised measure for allocating deprivation payments to general practitioners.

\section{Introduction}

The Jarman score for underprivileged areas is a measure of general practitioners' workload. As well as the recent prominence as a trigger for special payments to general practitioners the Jarman underprivileged area index has been used as an indicator of urban deprivation. It has also been used in health service planning, where it was put forward as a measure to help in the allocation of resources in the discussions taking place before the publication of Working for Patients in 1989.

In this paper I trace the development of the Jarman index and examine some criticisms and wider issues affecting measures of urban deprivation.

The 1981 Acheson committee, in their review of primary care in London, collected evidence about the social characteristics of the inner London population (such as how many elderly people there were living alone) and its need for primary care. ${ }^{2}$ Replies and evidence to the committee formed the basis of a questionnaire that was distributed by Jarman in 1981 to a national $10 \%$ sample of general practitioners selected from a commercial mailing list. ${ }^{3}$ Much of the later work emanating from Jarman's research rests on responses to the single question:

Below is a list of factors which evidence suggests contribute to the pressure of work on general practitioners. Based on experience in your own practice, could you please score each factor on a scale from 0 (no problem) to 9 (very problematical) according to the degree to which it increases workload or contributes to the pressure of work when it is present. Those factors which you do not mark will not be included in our final calculations.

Jarman gave attention to service factors in his 1983 paper, but it was "social factors alone... [that were] used to measure workload according to the general practitioner's assessments." 3 Ten such social indicators are taken into account in the calculation of the underprivileged area score.

A weighting procedure was adopted for calculating the underprivileged area score according to the average scores given in response to the above question. Table I gives the average score for each factor. To validate the index a matching procedure took place that compared maps showing areas of greatest workload or pressure compiled by local medical committees with those of Jarman's underprivileged area scores for the same geographical areas. ${ }^{4}$ In five family practitioner committee areas there was agreement on all but $6.3 \%$ of the wards. According to Jarman, variations in the method of calculating the scores has little effect on the ranking of ward scores.

The measure quickly gained the attention of health
Education, Doncaster

College, Doncaster

Robin J Talbot, PHD,

senior lecturer

$B M 7$ 1991;302:383-6 
TABLE I-Average score (on a scale of 0 to 9) for each social factor identified by Farman allocated by a $10 \%$ sample of general practitioners

\begin{tabular}{lc}
\hline Social factor & $\begin{array}{c}\text { Average } \\
\text { score }\end{array}$ \\
\hline Children aged $<5$ & $4 \cdot 64$ \\
Unemployment & $3 \cdot 34$ \\
Poor housing & $3 \cdot 60$ \\
Ethnic minorities (people born outside United Kingdom) & $2 \cdot 50$ \\
Single parent households & $3 \cdot 01$ \\
Elderly people living alone & $6 \cdot 62$ \\
Overcrowded households & $2 \cdot 88$ \\
Lower social classes & $3 \cdot 74$ \\
Highly mobile people (percentage changing house in a year) & $2 \cdot 68$ \\
Families of non-married couples (less stable family groups) & $2 \cdot 71$ \\
\hline
\end{tabular}

researchers. By 1984 a series of papers had both developed the use of underprivileged area scores and detailed their use as an information base for health planning. ${ }^{5}$

Further attention was drawn to the Jarman index with the publication of Promoting Better Health. ${ }^{6}$ Paragraph 3.38 states that "the Government will introduce a new allowance especially related to working in areas of deprivation." The paragraph does not state how this allowance will operate but it does promise an examination of the allowance arrangements, and "if necessary other changes in the remuneration system will be introduced."

A new basic practice allowance supplement for general practitioners practising in areas of deprivation in England ${ }^{7}$ was payable from 1 April $1990^{8}$ with respect to all patients on their lists who live in areas with underprivileged area scores of $>30 .^{3}$

\section{Criticisms of the Jarman index}

Problems arise in using the Jarman index; three areas of concern are described below.

TABLE II-Population size of enumeration districts in Doncaster Family Practitioner Committee according to dato published in $1981^{\circ}$

\begin{tabular}{lc}
\hline $\begin{array}{c}\text { Population } \\
\text { size }\end{array}$ & $\begin{array}{c}\text { No of } \\
\text { enumeration } \\
\text { districts }\end{array}$ \\
\hline$<100$ & $9+$ \\
$100-299$ & 49 \\
$300-499$ & 203 \\
$500-699$ & 290 \\
$700-999$ & 20 \\
$\geqslant 1000$ & 2 \\
\hline Total & 573 \\
\hline
\end{tabular}

$\star$ Mean (SD; range) population $=$ $496 \cdot 8(145 \cdot 6 ; 0-1124)$

tEnumeration districts

corresponding to areas undergoing redevelopment or large rural areas.

TABLE III-Underprivileged area scores for family practitioner committee areas $(n=98)$ in England and Wales'

\begin{tabular}{lc}
\hline $\begin{array}{l}\text { Family practitioner } \\
\text { committee area }\end{array}$ & $\begin{array}{c}\text { Under- } \\
\text { privileged } \\
\text { area score }\end{array}$ \\
\hline City and East London & 53.05 \\
Camden and Islington & 41.31 \\
$\begin{array}{l}\text { Lambeth, Southwark, } \\
\text { and Lewisham }\end{array}$ & $39 \cdot 76$ \\
Manchester & 37.73 \\
Bradford & 34.60 \\
Kensington, Chelsea, & \\
$\quad$ and Westminster & 33.95 \\
Rochdale & 26.45 \\
Birmingham & 25.65 \\
Liverpool & 25.61 \\
Oldham & 22.05 \\
\hline
\end{tabular}

\section{USE OF WARD AREAS OR ANOTHER AREA MEASURE}

Electoral wards are used as the geographical areas for which deprivation payments are made. For these new payments to general practitioners (with effect from 1 April 1990) the deprivation allowance is triggered where patients live in wards with an underprivileged area score of $>30$ (lower payment), $>40$ (middle payment), and $>50$ (higher payment). In addition, much attention is given to local health service planning at the ward level. However, wards vary considerably in size: in the Northern Regional Health Authority in 1981 the smallest ward had a population of 500 and the largest 15500 . As census figures are available at the enumeration district level it would be possible to obtain data for these units of analysis. Each ward area consists of several enumeration districts; these are delineated by the Office of Population Censuses and Surveys at each 10 year census and correspond to the areas covered by each census enumerator. In the case of Doncaster Family Practitioner Committee there are between 22 and 33 enumeration districts in each of its 21 wards. Table II gives a breakdown of population for the enumeration districts within the area of this committee according to data published in 1983. About $86 \%(493 / 573)$ of the districts had a population between 300 and 699.9

At the very least, use of enumeration districts would allow geographical areas of smaller size and with less variation in their population to be compared. Family practitioner committee registers have been allocated postcodes to help identify patients of deprived area status. ${ }^{10}$ The loading of such postcodes includes information relating to enumeration districts. No modification is being permitted of the levels of deprivation payment or of the breaking down of ward figures into enumeration districts. ${ }^{8}$ The introduction of the depri-

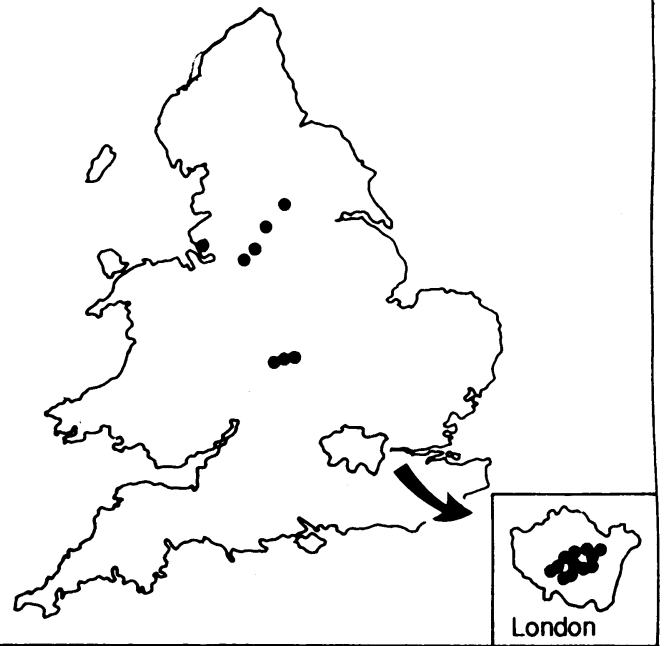

District health authorities in England with the 20 highest underprivileged area scores

vation payments and the designation of the levels of allowance has led to controversy among general practitioners. To overcome some of these problems Professor Jarman himself recommended that the score for the lower level of allowance should be set at $16 .{ }^{11}$

\section{DISCREPANCIES AND LONDON BIAS}

The figure shows the 20 districts with the highest underprivileged area scores among the 192 district health authorities. Seven of the authorities with one of the 10 highest scores and 12 of those with one of the 20 highest scores are in London; a further five London authorities (Haringey, Brent, Victoria, Greenwich, and Ealing) have underprivileged area scores between the fourth and fifth quintile of health districts.

Family practitioner committees cover larger geographical areas. Table III gives the 10 highest of the underprivileged area scores for the $\mathbf{9 8}$ family practitioner committees in England and Wales. ${ }^{12}$ The areas with the top three scores and four of the areas with the top six scores are in London. Another London committee (Ealing, Hammersmith, and Hounslow) has an underprivileged area score of $18 \cdot 88$.

Despite having the highest regional distribution in England of permanently sick people in 1981 and the highest figures for people certified as incapacitated because of sickness and invalidity in $1982-3^{13}$ no health authority or family practitioner committee from the Northern region appears in figure 1 or table III. The lack of any northern district with a score in the top 20 mirrors the comments of Townsend et al that this "flies in the face of most observation and experience." "14 The issue of bias towards London has been taken up by some northern authorities. ${ }^{15}$ Moreover, when attention is given to areas whose populations are classified as deprived large parts of the country are virtually excluded (table IV). Even some parts that obtain government funding and support for economic assistance or inner city regeneration are excluded from designation for the deprivation allowance; examples include Mid Glamorgan, Wakefield, and Doncaster.

In England and Wales 4.203 million (8.66\%) of the resident population of 48.520 million live in areas qualifying for the deprivation allowances. ${ }^{10}$ Again there is a considerable variation in the distribution of the population living in the designated deprived areas. In all, 1.467 million $(34.90 \%)$ of the 4.203 million population in these deprived areas live in London.

\section{ALTERNATIVE INDICES}

The Jarman index has been criticised by Thurnhurst ${ }^{16}$ and Carr-Hill and Sheldon (p 393) ${ }^{17}$ for its use of 
TABLE IV-Percentage of population living in areas classified as deprived in various family practitioner committees

\begin{tabular}{|c|c|}
\hline $\begin{array}{l}\text { Percentage of } \\
\text { population } \\
\text { living in areas } \\
\text { classified as } \\
\text { deprived }\end{array}$ & Family practitioner committee \\
\hline$>40 \%$ & $\begin{array}{l}\text { Camden and Islington; City and East London; Lambeth, } \\
\text { Southwark, and Lewisham }\end{array}$ \\
\hline $20-40 \%$ & $\begin{array}{l}\text { Birmingham; Bradford; Cleveland; Coventry; Ealing; } \\
\text { Hammersmith and Hounslow; Kensington, Chelsea, } \\
\text { and Westminster; Leeds; Liverpool; Manchester; } \\
\text { Newcastle upon Tyne; Rochdale; Wolverhampton }\end{array}$ \\
\hline $10-20 \%$ & $\begin{array}{l}\text { Bolton; Brent and Harrow; Bury; Calderdale; Enfield and } \\
\text { Haringey; Gateshead; Greenwich and Bexley; } \\
\text { Kirklees; Lancashire; Leicestershire; Oldham; } \\
\text { Salford; Sheffield; South Tyneside; Stockport; } \\
\text { Walsall; Wirral }\end{array}$ \\
\hline $5-10 \%$ & $\begin{array}{l}\text { Bedfordshire; Derbyshire; East Sussex; Humberside; } \\
\text { North Tyneside; Nottinghamshire; Redbridge and } \\
\text { Waltham Forest; Rotherham; Sandwell; St Helens and } \\
\text { Knowsley; Sunderland; Tameside }\end{array}$ \\
\hline $0 \cdot 01-5 \%$ & $\begin{array}{l}\text { Avon; Barking and Havering; Berkshire; Bromley; } \\
\text { Buckinghamshire; Cambridgeshire; Cheshire; Clwyd; } \\
\text { Devon; Dorset; Durham; Gwent; Gwynedd; } \\
\text { Hampshire; Hereford and Worcester; Kent; } \\
\text { Lincolnshire; Norfolk; Northamptonshire; } \\
\text { Northumberland; Sefton; Shropshire; Somerset; } \\
\text { South Glamorgan; Staffordshire; Suffolk; West } \\
\text { Glamorgan; Wiltshire }\end{array}$ \\
\hline 0 & $\begin{array}{l}\text { Barnet; Barnsley; Cornwall and Isles of Scilly; Croydon; } \\
\text { Cumbria; Doncaster; Dudley; Dyfed; Essex; } \\
\text { Gloucestershire; Hertfordshire; Hillingdon; Isle of } \\
\text { Wight; Kingston and Richmond; Merton, Sutton and } \\
\text { Wandsworth; Mid Glamorgan; North Yorkshire; } \\
\text { Oxfordshire; Powys; Solihull; Surrey; Trafford; } \\
\text { Wakefield; Warwickshire; West Sussex; Wigan }\end{array}$ \\
\hline
\end{tabular}

outdated census material from 1981 . The validity of its construction has also been criticised ${ }^{18}$ in that a measure of general practitioner workload has been applied to a wider concept - namely, that of deprivation or underprivilege. This has led to Townsend et al utilising different indicators in their studies of health and deprivation (box).

Townsend et al have presented alternative indices and their relation to indicators of poor health. ${ }^{14}$ Though there is a positive correlation between the Jarman index and other measures of deprivation and mortality, there is evidence that deprivation scores add little more to standardised mortality ratio values in explaining demand for health care as measured by bed days used in general hospitals. ${ }^{19}$

Hutchinson et $a l^{20}$ compared Jarman's index with that of Townsend et al. ${ }^{13}$ If the scores of Townsend et al for material deprivation were used for the allocation of financial resources to doctors in deprived areas some regions (for example, Northern and Mersey regions) would gain over $50 \%$ of their allocation, whereas other regions (such as East Anglia, Oxford, and South West Thames) would lose over $30 \%$.

\section{Deprivation indices}

Much attention has been given to the Jarman index by health authorities and local government. Though designed to measure the workload of doctors, the Jarman index has also been used as a general deprivation measure. For example, Coopers and Lybrand in their review of the Resource Allocation Working Party formula for their allocation of hospital and community services resources to regional health authorities selected the Jarman index rather than any other index of deprivation as their proposed formula. ${ }^{21}$ In Working for Patients the Department of Health moved away from that proposal by a commitment to a funding arrangement for health authorities on a capitation basis, weighted to reflect the health and age distribution of the population. Though not adopted for health authorities, it is interesting that the Jarman index was chosen to delimit areas for deprivation payments for general practitioners instead of other indices that might seem to be more appropriate.
Since the passage of the National Health Service and Community Care Act 1990 family practitioner committees have been abolished and replaced by family health services authorities, and previous open ended funding arrangements for ancillary staff and improvements in surgery have been replaced by cash limited budgets. Amid these structural changes another process, on a smaller scale than the reallocation of funds for hospital and community services-namely, that of the equalisation and compensation of resources for family practitioner committees in $1987^{6}$ - has been lost owing to opposition from some family practitioner committees (communication to administrators of family practitioner committees from Society of Family Practitioner Committees, 1987). It is unclear what formulas will be used by regional health authorities in their allocation of funds to family health services authorities from April 1991.

The study of indicators of urban deprivation has received much attention by geographers and social scientists during the past 20 years. ${ }^{22} 23$ Government policies have long favoured some form of targeting of resources into areas of concentrated urban deprivation. As Church and Hall explain in their commentary on central government policies for intervention in regeneration of urban areas, the selection of deserving areas is "broadly systematic and 'objective'."'24 In a period of limited public resources, when distribution of scarce resources is socially controlled ${ }^{25}$ and the struggle for these resources generates conflict, ${ }^{26}$ the selection and analysis of "objective" indicators become important factors when applied to the allocation of funds and allowances from the Department of Health. Though there is a lobbying procedure for allocation of funds, and this has been recognised in other areas of urban policy such as allocations of regional funding ${ }^{24}$ the use of any statistical measure that gives advantage to any area at expense of another is worthy of attention.

As service factors were removed from the original Jarman study there is a danger that problems of health related services themselves are not identified as issues affecting underprivileged areas. By concentrating on "social" factors alone ${ }^{27}$ this suggests a shift in the rationale underpinning underprivilege and deprivation away from institutional malfunctioning and maldistribution of resources and opportunities to that of cycles of poverty and deprivation.

\section{Conclusions}

Use of the Jarman index as a measure of deprivation leads to a counterintuitive distribution of "deprived"

\section{Deprivation variables utilised by Townsend, et al $^{14}$}

(1) Percentage of economically active residents aged 16-59 or 16-64 who are unemployed

(2) Percentage of private households that do not possess a car

(3) Percentage of private households that are not owner occupied

(4) Percentage of private households with $>1$ person per room

Measures of 1-4 were combined to form an overall deprivation index.

Other measures included:

(5) Percentage of 17 year olds not in full time education

(6) Percentage of private households without exclusive use of bath and toilet

(7) Percentage of private households with at least one single parent family with dependent child(ren) aged $0-15$ years

(8) Percentage of households in which the economic head is in social class IV or $\mathrm{V}$ 
areas. In particular, there is a strong bias towards London in the proportion of the population classified as deprived. The index fails to recognise the nature of deprivation in the north of England, and, utilising Jarman's index, any resource allocation exercise would benefit the Thames regions at the expense of peripheral regions. Also, the Jarman index has been used outside its original domain of application-namely, that of general practitioners' workload - to guide the allocation of both health care and other resources. This raises the issue of how a statistical index develops a life of its own.

I thank Doug Anderson and Bill Wood of Doncaster College for their comments on an earlier draft of this paper and Roy Carr-Hill and Trevor Sheldon for comments on a later draft.

1 Secretaries of State for Health, Wales, Northern Ireland, and Scotland. Working for patients. London: HMSO, 1989. (Cmnd 555 .)

2 Acheson D. Primary health care in inner London. London: Department of Health and Social Security, 1981. (Report of a study group commissioned by the London Health Planning Consortium

Jarman B. Identification of underprivileged areas. BMF 1983;286:1705-9.

4 Jarman B. Underprivileged areas: validation and distribution of scores. $B M \mathcal{F}$ 984;289:1587-92.

Irving D, Rice P. Information for health services planning from the 1981 census 84/11. London: Kings Fund, 1984

6 Secretaries of State for Social Services, Wales, Northern Ireland, and Scotland. Promoting better health. London: HMSO, 1987. (Cmnd 249.)

7 Department of Health. General practice in the National Health Service: the 1990 contract. London: HMSO, 1989.

8 Department of Health. Deprived areas: remuneration for GMPs. London: DoH 1990. (FPCL 46/90.
Office of Population Census and Surveys. Doncaster metropolitan borough council: small area statistics. London: HMSO, 1983.

10 Family Practitioner Services Computer Unit. Loading of deprived area status against postcode. Exeter: FPS Computer Unit, 26 February 1990.

11 Brindle D. "Deprived area" ruling cuts out extra payments for many GPs. Guardian 1990 Feb 16:2.

12 Jarman B. Underprivileged areas in the medical annual. Bristol: John Wright, 1985

13 Townsend P, Phillimore P, Beattie A. Health and deprivation: inequality and the north. London: Croom Helm, 1988

14 Townsend P, Phillimore P, Beattie A. Inequalities in health in the northern region: an interim report. Bristol: Northern Regional Health Authority, 1986. 15 Anonymous. FPC cites index bias to London. Doctor 1990 Feb 1:18

16 Thurnhurst $C$. The analysis of small area statistics and planning for health Statistician 1985;34:93-106.

17 Carr-Hill R, Sheldon T. Designing a deprivation payment for general practitioners: the UPA (8) wonderland. BMF 1991;302:393-6.

18 Whitehead M. The health divide: inequalities in health in the 1980s. London: Penguin, 1988

19 Carstairs V, Morris R. Deprivation, mortality and resource allocation. Community Med 1989:11:364-72.

20 Hutchinson A, Fry C, Sandhu B. Comparison of two scores for allocating resources to doctors in deprived areas. BMF 1989;299:1142-4.

21 Coopers and Lybrand. Integrated analysis for the review of RAWP. London: Coopers and Lybrand, 1988.

22 Hatch $S$, Sherrott $R$. Positive discrimination and the distributions of deprivations. Policy and Politics 1973;1:223-40.

23 Smith DM. The identification of problems in cities: applications of social indicators. In: Herbert DT, Smith DM, eds. Social problems and the city. Oxford: Oxford University Press, 1979:13-32

24 Church AP, Hall JM. Local initiatives for economic regeneration. In: Herbert DT, Smith DM, eds. Social problems and the city. Oxford: Oxford University Press, 1989

25 Pahl RE. Socio-political factors in resource allocation. In: Herbert DT, Smith DM, eds. Social problems and the city. Oxford: Oxford University Press, 1979

26 Collins R. Conflict sociology. New York: Academic Press, 1975.

27 Hamnett C. Area-based explanations: a critical appraisal. In: Herbert DT, Smith DM, eds. Social problems and the city. Oxford: Oxford University Press, 1979 .

(Accepted 7 fanuary 199l)
University Department of Surgery, Royal Infirmary of Edinburgh, Edinburgh EH3 9YW

$\mathrm{J} M$ Dixon, FRCS, lecturer in surgery

Medical Statistics Unit, Medical School, Edinburgh R A Elton, PHD, senior lecturer

Department of Surgery, St John's Hospital at Howden Livingston, West Lothian

J B Rainey, FRCS, consultant surgeon

D A D Macleod, FRCS, consultant surgeon

Correspondence and requests for reprints to: Mr Dixon.

BMf 1991;302:386-8

\title{
Rectal examination in patients with pain in the right lower quadrant of the abdomen
}

\author{
J M Dixon, R A Elton, J B Rainey, D A D Macleod
}

Abstract

Objective-To determine whether rectal examination provides any diagnostic information in patients admitted to hospital with pain in the right lower quadrant of the abdomen.

Design-Casualty officer or surgical registrar recorded symptoms and signs on admission on detailed forms. Final diagnosis was noted on discharge from hospital.

Setting-District general hospital.

Patients-1204 Consecutive patients admitted to hospital with pain in the right lower quadrant of the abdomen as their major complaint; 1028 had a rectal examination on admission.

Main outcome measures-Odds ratio for each symptom and sign related to final diagnosis. Results of multiple logistic regression analysis for acute appendicitis.

Results - Right sided rectal tenderness, present in 309 of those examined, was more common in patients with acute appendicitis (odds ratio $1.34, p<0.05$ ). This odds ratio was considerably less than that for other clinical signs-namely, tenderness in the right lower quadrant (odds ratio 5.09), rebound tenderness (3.34), guarding (3.07), and muscular rigidity in the abdomen (5.03). In the logistic regression analysis of patients with acute appendicitis, when allowance was made for the presence or absence of rebound tenderness, rectal tenderness on the right lost its significance. Six patients had masses palpable rectally, of which three were palpable on abdominal examination; the other three patients had acute appendicitis. No other unexpected diagnoses were established, and no useful additional diagnostic information was obtained by routine rectal examination.

Conclusion-If patients presenting with pain in the right lower quadrant of the abdomen are tested for rebound tenderness then rectal examination does not give any further diagnostic information.

\section{Introduction}

The diagnosis of the cause of pain in the right lower quadrant of the abdomen rests largely on the clinical history and results of clinical examination. Rectal examination is considered to be essential in this evaluation, ${ }^{12}$ but it is unpleasant for the patient, particularly when it is repeated by different doctors, and there is scant evidence that it provides any information of diagnostic value. ${ }^{3-5}$ We aimed to assess whether rectal examination is valuable in determining the diagnosis in patients admitted to hospital with pain in the right lower quadrant of the abdomen.

\section{Patients and methods}

We studied 1204 consecutive patients admitted to Bangour General Hospital between September 1983 and June 1989 with pain in the right lower quadrant of the abdomen as their main presenting complaint. At the time of admission a casualty officer or surgical registrar recorded on to a detailed form the patient's age, sex, and symptoms and the findings on clinical examination; these data were then entered and stored in a BBC microcomputer. Rectal examination was recorded as having been performed at admission in $1028(85 \%)$ patients, and rectal tenderness, if present, 